\title{
Growth and condition of juvenile sole (Solea solea L.) as indicators of habitat quality in coastal and estuarine nurseries in the Bay of Biscay with a focus on sites exposed to the Erika oil spill
}

\author{
CAMILLE GILLIERS ${ }^{1}$, OLIVIER LE PAPE ${ }^{2}$, YVES DÉSAUNAY ${ }^{3}$, JEAN-PIERRE $^{2}$ \\ BERGERON $^{3}$, NATHALIE SCHREIBER ${ }^{3}$, DANIEL GUERAULT ${ }^{3}$ and RACHID AMARA ${ }^{4}$ \\ ${ }^{1}$ Université de Lille I, Laboratoire Econum-Ecotox, Cité Scientifique bât SN3, F-56655 Villeneuve d'Ascq Cedex, France. \\ E-mail: camille.gilliers@mren2.univ-littoral.fr \\ ${ }^{2}$ Pôle Halieutique, Agrocampus Rennes, 65 rue de St Brieuc, CS 84215, 35042 Rennes, France. \\ ${ }^{3}$ IFREMER, Département Ecologie et modèles pour l'halieutique, rue de l'Ile d'Yeu, B.P. 21105 , \\ 44311 Nantes cedex 03, France. \\ ${ }^{4}$ Université du Littoral Côte d'Opale, UPRESS-A ELICO 8013 CNRS, avenue Foch, B.P. 59, 62930 Wimereux, France.
}

\begin{abstract}
SUMMARY: Indicators of growth and condition were used to compare the habitat quality of nurseries of juvenile sole (Solea solea L.) in the Bay of Biscay, based on one survey in 2000. The four biological indicators are poorly correlated with each other, suggesting that no single measure may give an adequate description of fish health and of its habitat's quality. Growth indicators showed significant differences between northern and southern areas. Juveniles from the two southernmost nurseries, the Gironde estuary and the Pertuis Antioche, displayed significant lower otolith increment widths and mean sizes. These differences were inversely related to water temperature and unrelated to genetic or age differences, and are unlikely to be due to limiting trophic conditions in the nurseries. Hence, they may be considered in terms of differences in habitat quality and potential anthropogenic impacts. Condition indices do not show this north-south pattern but highlight low condition values in the Pertuis Antioche. Shortterm and fluctuating biochemical indicators such as RNA/DNA ratios appeared to be unreliable over a long-term study, while morphometric indices seemed to be relevant, complementary indicators as they integrate the whole juvenile life-history of sole in the nurseries. The growth and condition indices of juveniles in September 2000 from nursery grounds exposed to the Erika oil spill in December 1999 were relatively high. These results lead us to suggest that there was no obvious impact of this event on the health of juvenile sole and on the quality of the exposed nursery grounds a few months after the event.
\end{abstract}

Keywords: essential fish habitat, otolith daily increment width, RNA/DNA, Erika oil spill.

RESUMEN: CRECIMIENTO Y CONDICIÓN DE JUVENILES DE LENGUADO (SOLEA SOLEA L.) COMO INDICADORES DE CALIDAD DE HÁBITAT EN ÁREAS DE CRÍA COSTERAS Y ESTUÁRICAS DEL GOLFO DE VIZCAYA CON ÉNFASIS EN ZONAS EXPUESTAS AL VERTIDO DEL ERIKA. - Se usaron indicadores de crecimiento y condición de lenguados juveniles (Solea solea L.) para comparar la calidad del hábitat de áreas de cría en el Golfo de Vizcaya basados en un muestreo de 2000. Los cuatro indicadores biológicos mostraron bajas correlaciones entre sí, lo que sugiere que no existe una medida única para describir adecuadamente el estado de los peces y la calidad de su hábitat. Los indicadores de crecimiento mostraron diferencias significativas entre las áreas septentrionales y meridionales. Los juveniles de las áreas situadas más al sur: el estuario del Garona y Pertuis Antioche mostraron incrementos de otolitos y tamaños medios significativamente inferiores. Estas diferencias están inversamente relacionadas con la temperatura del agua, pero no con diferencias genéticas o de edad, y no es probable que se deba a una condición trófica limitante en las áreas de cría. Por tanto, pueden considerarse en términos de calidad del hábitat y el potencial impacto antropogénico. Los índices de condición no muestras este patrón norte-sur sino que destacan los bajos valores de condición en Pertuis Antioche. Los indicadores bioquímicos variables de corto término como las relaciones RNA/DNA no parecieron fiables para estudios de mayor escala, mientras que los índices morfométricos parecen ser relevantes y complementarios ya que integran toda el período juvenil de la vida de los lenguados en sus áreas de cría. Los valores de crecimiento y condición de juveniles en septiembre de 2000 en áreas de cría expuestas al vertido de crudo del Erika en diciembre de 1999 fueron relativamente elevadas. Estos resultados sugieren que no hubo un impacto obvio de este evento sobre la salud de los juveniles de lenguado ni en la calidad de las áreas de cría expuestas transcurridos unos pocos meses después del vertido. 


\section{INTRODUCTION}

Despite evidence of important ecological linkages between environmental conditions and fishery production (Engel et al., 1999), the management of commercial fishery resources has historically concentrated on assessing stock size and controlling fishing mortality. However, the conservation and management of fishery habitats has become an important component of comprehensive fishery management programmes (Minello, 1999). Coastal marine areas are particularly sensitive fish habitats because they have an important function as nursery grounds for commercially important marine fish species (Costanza et al., 1997). Habitat degradation is one of the main causes of the decline or extinction of species (Gibson, 1994). Coastal and estuarine nursery areas are subjected to a wide range of stressors. Anthropogenic factors, ranging from habitat destruction to pollution, are superimposed on natural fluctuant factors such as food quantity and quality, water temperature and level of predation. The habitat quality of the nurseries has potential effects on the growth and survival of the juvenile fish and ultimately on their recruitment. Hence, the assessment and the conservation of habitat quality, particularly for species of economic importance, are becoming ongoing concerns (Able, 1999). Highquality nursery habitats are assumed to be those where growth and survival of juvenile fish are enhanced and where reproductive potential is optimised (Gibson, 1994). Hence, estimations of growth and condition of young fish are often used as a mean to assess the effects of environmental conditions on individuals in order to appreciate their habitat quality (Sogard and Able, 1992; Phelan et al., 2000; Stunz et al,. 2002; Lloret et al., 2003).

Inshore shallow waters and estuaries along the coastline of the French part of the Bay of Biscay provide nursery areas that have been identified as Essential Fish Habitats for commercial fish, and especially common sole (Solea solea L.)(Le Pape et $a l ., 2003)$. The objectives of this study were to compare the habitat quality of several nursery areas of the Bay of Biscay.

We hypothesised that the health of juvenile common sole must be influenced by the quality of their nursery habitat. We used biochemical, morphometric and otolith indices to assess the general health of juvenile fish and to evaluate their nursery habitat quality. We also hypothesised that condition and growth must be lower in areas known to be damaged by human activities (Burke et al., 1993; Able et al., 1999; Lloret et al., 2003), such as the important estuaries (Burgeot et al., 1999), paying special attention to the northern nursery grounds in the Bay of Biscay that were exposed to the Erika oil spill in December 1999.

\section{MATERIALS AND METHODS}

The target species is the common sole (Solea solea $\mathrm{L}$.). It is one of the most important commercial species in the Bay of Biscay (ICES Division VIII $\mathrm{a}, \mathrm{b})$ and is considered as a homogeneous population and a unique stock (Koutsikopoulos et al., 1995). Adults spawn from January to April in water depths of $40-100 \mathrm{~m}$ at a distance of 40 to $80 \mathrm{~km}$ offshore (Arbault et al., 1986; Koutsikopoulos and Lacroix, 1992). Pelagic larvae close to metamorphosis and newly settled benthic juveniles enter the bays and estuaries by late April (Marchand and Masson, 1989). 0-group juveniles are concentrated in these bays and estuaries in summer and are not found offshore (Koutsikopoulos et al., 1989). Because early juveniles are sensitive to environmental changes and do not interact with other nursery grounds in the Bay of Biscay (Koutsikopoulos et al., 1989), the indicator measurements should properly reflect the condition at the different sampled nursery sites.

\section{Study area and sample collections}

The coastal shelf of the Bay of Biscay extends $160 \mathrm{~km}$ from the coast in the north and narrows to $65 \mathrm{~km}$ in the south, and underlies most of the Bay of Biscay. Tidal currents are weak $\left(<30 \mathrm{~cm} . \mathrm{s}^{-1}\right)$ in this area, their direction is location-dependent and the general residual circulation is parallel to the coast (Le Cann, 1990). We prospected various costal and estuarine nursery areas which show different characteristics. The shore of the Bay of Biscay is partitioned into open shallow muddy estuarine areas under the direct influence of freshwater inflows from the Vilaine (average river flow: $91 \mathrm{~m}^{3} \cdot \mathrm{s}^{-1}$ ), the Loire (average river flow: $935 \mathrm{~m}^{3} \cdot \mathrm{s}^{-1}$ ) and the Dordogne and Garonne forming the Gironde estuary (average river flow: $780 \mathrm{~m}^{3} . \mathrm{s}^{-1}$ ); and semi-enclosed sheltered marsh areas with shellfish farming that are little affected by rivers: the Bay of Bourgneuf and the Pertuis Breton and Antioche. All these coastal 


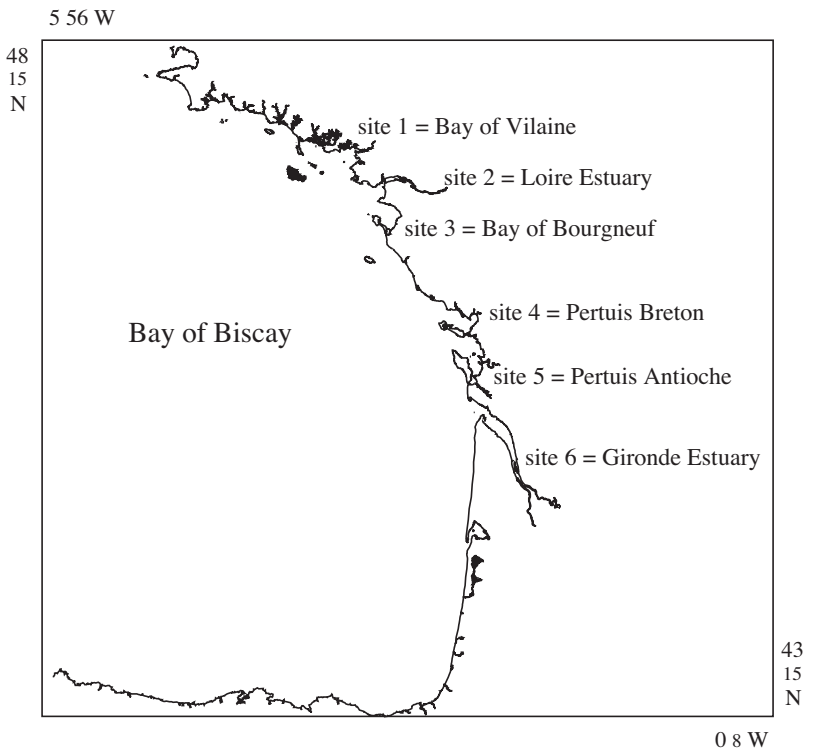

FIG. 1. - Localisation of the 6 sampled sites in the Bay of Biscay.

and estuarine sectors provide highly productive areas where ichthyofauna is dominated by juvenile fish of commercial species such as common sole (Solea solea), whiting (Merlangius merlangus), bib (Trisopterus luscus), red mullet (Mullus surmeletus) and wedge sole (Dicologoglossa cuneata), and noncommercial species such as black goby (Gobius niger), sand goby (Pomatoschistus minutus), dragonet (Callionimus lyra) and solennette (Buglossidium luteum) (Désaunay et al. 2003).

Sole juveniles were collected in 6 nursery grounds in the French part of the Bay of Biscay from the Bay of Vilaine to the Gironde estuary (Fig. 1) during the "NURSE" survey in September 2000 (R.V. Gwendrez). Autumn was chosen because it corresponds to the end of the growing season of juvenile sole in these nursery grounds. At this time, the distribution of juvenile soles is representative of the productive period and these YoY fish have not moved from the nursery since their settlement
(Dorel et al., 1991). Moreover, the problems of selectivity and size-dependent catchability for trawling - both very important factors in early summerare limited at the end of the growing period (Riou et al., 2001).

Samples were obtained with a $3 \mathrm{~m}$ beam trawl (stretched mesh size of $20 \mathrm{~mm}$ ) at depths of 5 to 25 $\mathrm{m}$ at each site. The 3 northern nursery grounds (Bay of Vilaine, Loire estuary and Bay of Bourgneuf) were exposed to the Erika oil spill in December 1999. All the sole caught were counted and measured to the nearest $\mathrm{cm}$ (total length, TL). The identification of the 0-group sole was performed using length-frequency analysis and confirmed from examination of otoliths. A total number of 38820 group juvenile soles were caught during the survey.

For each site and for the 0-group sole, 5 individuals for each $\mathrm{cm}$ length-class in the range of catches were immediately frozen at $-20^{\circ} \mathrm{C}$. In the laboratory, a subsample of 193 0-group juvenile soles was used for the growth and condition analyses. Standard length (SL) was used in the condition analyses to allow for damage to the caudal fin rays.

All the survey data are summed up in Table 1.

\section{Condition indices}

\section{RNA/DNA ratio}

RNA and DNA concentrations (mg. $\mathrm{l}^{-1}$ ) were determined for each individual on a white muscle sample with the spectrofluorimetric method described by Le Pecq and Paoletti (1966) and modified by Karsten and Wollenberger (1977) using ethidium bromide and type I DNA purified from calf thymus as a standard. For each individual, a sample of white muscle was homogenised in ice-cold phosphate-buffered saline (PBS) with a Potter and a Polytron homogeniser. Two $0.5 \mathrm{~mL}$-aliquots were

TABLE 1. - Samples description: 0-group juvenile soles from total catches from the survey and for laboratory analyses (RNA/DNA, condition factor $(\mathrm{R})$, and recent growth index $(\mathrm{RG})$ ) with their size ranges (Total Length TL $(\mathrm{cm})$ ).

\begin{tabular}{|c|c|c|c|c|c|c|c|c|}
\hline \multirow[b]{2}{*}{ Site } & \multirow[b]{2}{*}{ Latitude } & \multirow[b]{2}{*}{ Date } & \multirow[b]{2}{*}{$\begin{array}{l}\text { Number } \\
\text { of trawls }\end{array}$} & \multirow[b]{2}{*}{$\begin{array}{c}\text { Temp. } \\
\left({ }^{\circ} \mathrm{C}\right)\end{array}$} & \multicolumn{2}{|c|}{$\begin{array}{l}\text { Total } 0 \text {-group juvenile } \\
\text { sole captures }\end{array}$} & \multicolumn{2}{|c|}{$\begin{array}{l}\text { Subsample of 0-group juvenile } \\
\text { sole for laboratory analyses }\end{array}$} \\
\hline & & & & & $\begin{array}{c}\text { Total number of } \\
\text { individuals caught }\end{array}$ & $\begin{array}{c}\text { Size range } \\
\text { TL }(\mathrm{cm})\end{array}$ & $\begin{array}{c}\text { Number of } \\
\text { individuals analysed }\end{array}$ & $\begin{array}{l}\text { Size range } \\
\mathrm{TL}(\mathrm{cm})\end{array}$ \\
\hline 1 - Bay of Vilaine & $47^{\circ} 25.44^{\prime} \mathrm{N}$ & 23-25 Sept. 00 & 33 & 18.30 & 759 & $9 \leq \mathrm{TL} \leq 17$ & $9.9 \leq$ & $\leq \mathrm{TL} \leq 14.30$ \\
\hline 2 - Loire estuary & $47^{\circ} 10.16^{\prime} \mathrm{N}$ & 17-18 Sept. 00 & 26 & 17.37 & 111 & $8 \leq \mathrm{TL} \leq 14$ & $8.7 \leq$ & $\leq \mathrm{TL} \leq 14.10$ \\
\hline 3 - Bay of Bourgneuf & $47^{\circ} 04.20^{\prime} \mathrm{N}$ & 18-22 Sept. 00 & 21 & 18.50 & 639 & $7 \leq \mathrm{TL} \leq 15$ & $8.3 \leq$ & $\leq \mathrm{TL} \leq 12.30$ \\
\hline 4 - Pertuis Breton & $46^{\circ} 15.74^{\prime} \mathrm{N}$ & $15-16$ sept. 00 & 17 & 19.96 & 937 & $7 \leq \mathrm{TL} \leq 16$ & $8.0 \leq$ & $\leq \mathrm{TL} \leq 14.20$ \\
\hline 5 - Pertuis Antioche & $46^{\circ} 02.66^{\prime} \mathrm{N}$ & 14 Sept. 00 & 24 & 20.05 & 1003 & $7 \leq \mathrm{TL} \leq 15$ & $6.8 \leq$ & $\leq \mathrm{TL} \leq 13.90$ \\
\hline 6 - Gironde estuary & $45^{\circ} 40.25^{\prime} \mathrm{N}$ & 10-11 Sept. 00 & 23 & 19.50 & 433 & $6 \leq \mathrm{TL} \leq 15$ & $6.5 \leq$ & $\leq \mathrm{TL} \leq 12.30$ \\
\hline
\end{tabular}


used to measure DNA total nucleic acids, which meant adding heparin to dissociate the nucleoproteins, plus ethidium bromide, and then measuring total fluorescence. Two more aliquots were used to measure the DNA concentration by adding $0.5 \mathrm{~mL}$ of heparin plus $0.5 \mathrm{~mL}$ of RNAse (purified from bovine pancreas) to digest the RNA (30 minutes' incubation), leaving only the DNA. A fifth aliquot was used to measure background fluorescence; no ethidium bromide was added to this aliquot. A sixth blank aliquot containing only PBS was run each day to calibrate the spectrofluorimeter. Fluorescence was assessed on a KONTRON SFM-25 fluorescence spectrophotometer. A $360 \mathrm{~nm}$ filter was used for excitation, and emission was set at $590 \mathrm{~nm}$.

\section{Condition factor $(R)$}

Standard fish length (SL) measured to the nearest $\mathrm{mm}$ and wet weight (W) measured to the nearest $\mathrm{mg}$ were recorded. We examined the residuals derived from the logged length-weight relationship, i.e. the deviation of predicted weight estimated from the common logged length-weight relationship in terms of general fish condition (Blackwell et al. 2000). We computed the condition factor according to $\mathrm{R}=\log$ $\mathrm{W}-\log \mathrm{Wc}$, where $\mathrm{W}$ is the wet weight observed and $\mathrm{Wc}$ is the computed weight according to the logged length-weight relationship. $\mathrm{R}$ gives the relative condition of each fish compared with the average. The condition of fish is proportional to the residual values.

\section{Recent growth index (RG)}

\section{Otolith preparation and measurements}

Sagittal otoliths were used for the microstructure analysis. Only one sagitta was used because a preliminary examination showed the left and right sagittae to be identical with regard to the microstructure. We chose the right sagitta because the anterodorsal/postero-ventral axis provides the maximum growth axis due to nucleus off-centering. All increment width measurements were made as far as possible along this axis. The right sagittae were then removed, cleaned in distilled water, and dried in an oven $\left(24 \mathrm{~h}\right.$ at $\left.60^{\circ} \mathrm{C}\right)$. They were mounted with the convex side up on standard microscope slides and embedded in glue (cyanoacrylate). Because sagittal otoliths are convex, the maximal growth axis does not include the nucleus. To ensure measures of the radius, all sagittae were first polished by hand on one side in the sagittal plane using aluminium powder $(0,1 \mu \mathrm{m})$ until the mid-plane (including the nucleus) was reached. The radius was measured under a stereomicroscope (magnification $24 \mathrm{x}$ ) connected to an image analysis system. The right sagittae were then polished again past the mid-plane, until the peripheral increments were reached. The otoliths were then etched for 3-4 minutes with $0.1 \mathrm{M}$ EDTA (ethylenediamine tetraacetate) $(5 \%, \mathrm{pH}=$ 7.5) and rinsed with distilled water. Because we were not able to reach the same number of outer increments for all otoliths, we chose to measure the 10 outer ones. Increment widths were measured 3 times for each otolith as described above using a light microscope (magnification $312.5 \mathrm{x}$ ), and the average was used for the statistical analysis. Because the increment widths of all otoliths were far greater than the light microscopy resolution limit of $0.2 \mu \mathrm{m}$ (Campana et al., 1987), SEM techniques were not required.

\section{Prerequisities of otolith microstructure analysis}

\section{Validation of daily increment deposition}

The daily increment deposition of sole sagittal otolith was validated on larval stages by Lagardère (1989) and on juvenile stages by Lagardère et al. (unpublished data).

\section{Otolith growth - fish growth relationship}

We found a significant linear relationship between the maximum radius of the right sagittal otolith and the standard length (SL) of the analysed juveniles (Fig. 2). Thus, the otolith growth, in terms of increment widths, reflects somatic growth of 0group juvenile soles (Campana and Neilson, 1985).

\section{Daily increment width - otolith size relationship}

The increment width is closely related to the otolith radius with marginal (border) increments tending to be wider. Hovenkamp and Witte (1991) advise using the residuals derived from the logged increment width/otolith radius relationship to compare different growth patterns. As explained above, we standardised all measurements of increment widths to the ten marginal daily increments. Hence, we compared increments formed at approximately the same radii for each individual at each site. We did not find any significant linear relationship 


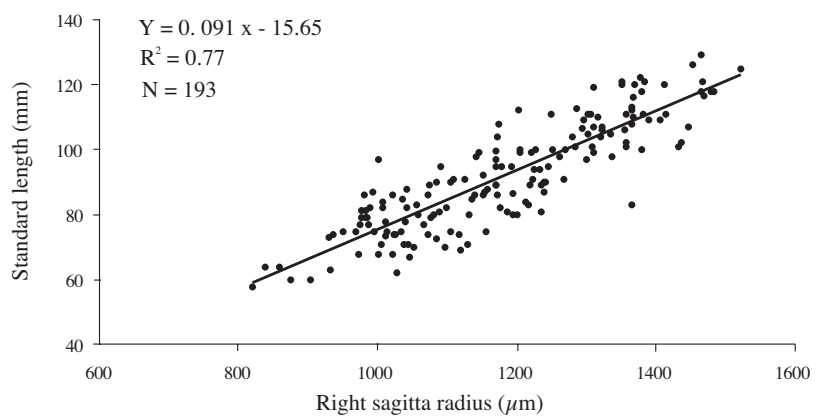

FIG. 2. - Relationship between right sagitta radius and standard length of the 193 0-group juvenile soles (subsample for laboratory analyses) collected at the 6 sites.

between increment width and increment radius (the distance from the increment to the otolith nucleus), which suggests that, in our case, the measures of increment widths are not biased by the otolith size. Subsequently, we compared the recent growth of the individuals directly by means of the widths of the marginal increments.

\section{Length (L) and density (D) of 0-group juveniles}

These additional indicators were not computed for the 193 sampled fish but for the 0-group juvenile sole from the entire catches during the survey. Mean total length (L) (cm) and density (D) (ind / $10000 \mathrm{~m}^{2}$ ) in depth from 5 to $10 \mathrm{~m}$ were computed from the survey. The average bottom temperature $(\mathrm{T})$ was also calculated at each site for depth $\geq 10 \mathrm{~m}$. As the size and the density of juvenile soles depend on the bathymetry, we chose this method to avoid any possible bias in sampling between sites and to standardise the data. This range of depths is supposed to be representative of 0group sole distribution in autumn, as described by Dorel et al. (1991) in the Bay of Vilaine.

\section{Data analyses}

One way ANOVAs were used to test for significant differences in recent growth index,
RNA/DNA ratio, and 0-group mean length and density between the 6 sampled sites. One way ANCOVAs on the juveniles' logged length-weight relationship were used to test for significant differences in condition between the 6 sites. Tukey's honest significant differences (HSD) test was used for multiple comparisons after ANOVA or ANCOVA. Simple linear least-squares regressions were conducted to examine the relationship between the various indices with the 0-group mean length and density, the latitude and the bottom temperature. The distribution of the data allows these parametric methods to be used without contra-indications. A p-value of 0.05 or less was considered statistically significant. Statistical analyses were conducted with Splus 2000 software.

Box plots were chosen to represent the distribution of the value of the RNA/DNA ratio, the condition factor, the recent growth index and the mean total length at each site (Fig. 3a,b,c,d), because they provide a convenient way to inspect the characteristics of the entire statistical distributions visually. Box plots enable simultaneous control of central tendency (medians) and sample variability (interquartile range).

\section{RESULTS}

\section{Spatial variations of condition indices}

\section{RNA/DNA ratio}

The ANOVAs discriminated significant contrasts between sites (Table 2). Individuals collected in the Bay of Vilaine (1) and in the Pertuis Antioche (5) showed the lowest ratios in comparisons with the other sites $(2,3,4,6)$ (Fig. 3a, Table 2). RNA/DNA ratios were not significantly linked to the other indicators (Table 3).

TABLE 2. - ANOVA results for comparisons between the 6 sampled sites: RNA/DNA ratios, R condition factor (mg), RG recent growth index (mean width of the last 10-day increments $(\mu \mathrm{m})$ ), L total length $(\mathrm{cm})$ and D density (ind/10000 $\mathrm{m}^{2}$ ) of total 0-group juvenile sole catches computed from the survey and $\mathrm{T}$ bottom temperature $\left({ }^{\circ} \mathrm{C}\right)$; d.f. $=$ degrees of freedom; S.S.= sum of squares; $\mathrm{F}=$ Fisher score; $\mathrm{p}=\mathrm{p}$-values of the test.

\begin{tabular}{|c|c|c|c|c|c|}
\hline Source & $\mathrm{df}$ & SS & $\mathrm{F}$ & $\mathrm{p}$ & Tukey test \\
\hline $\begin{array}{l}\text { RNA/DNA } \\
\text { R } \\
\text { RG } \\
\text { L } \\
\text { D }\end{array}$ & $\begin{array}{l}5 \\
5 \\
5 \\
5 \\
5\end{array}$ & $\begin{array}{r}13.72 \\
0.04 \\
48.07 \\
293.54 \\
1094177\end{array}$ & $\begin{array}{l}2.99 \\
5.48 \\
5.28 \\
5.34 \mathrm{e}+032 \\
3.35 \mathrm{e}+031\end{array}$ & $\begin{aligned} & 0.0128 \\
< & 0.001 \\
< & 0.001 \\
< & 0.001 \\
< & 0.001\end{aligned}$ & $\begin{array}{l}2=3=4=6>1=5 \\
1=6>2=3=4=5 \\
1=2=3>4=5=6 \\
1>2=4>3=5=6 \\
5>1=2=3=4=6\end{array}$ \\
\hline
\end{tabular}



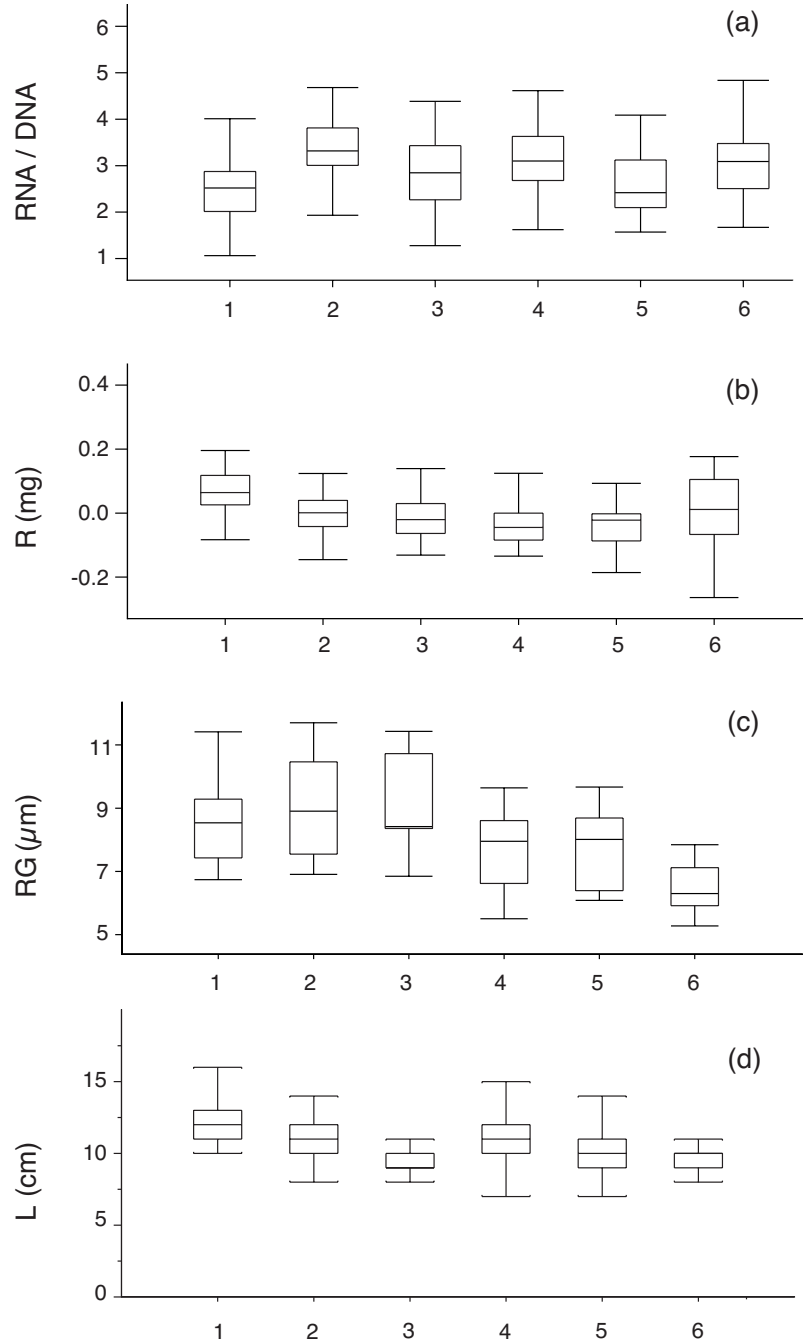

FIG. 3. - Differences between the sites for the indices measured in 193 0-group soles: (a) the biochemical index RNA/DNA, (b) the condition factor R (mg), (c) the recent growth index RG as mean width $(\mu \mathrm{m})$ of the last 10-day otolith increments and for an additional indicator computed from the total catches during the survey: (d) 0-group soles length $\mathrm{L}$ (total length $(\mathrm{cm})$ ).

\section{Condition factor $(R)$}

The ANCOVAs showed significant differences between the sites (Table 2) and multiple comparisons showed that individuals from the Bay of Vilaine (1) and the Gironde estuary (6) significantly displayed the greatest values for this indicator (Table 2, Fig. 3b). Weak but significant relationships (Table 3) were found between the condition factor and the 0-group juveniles mean density (negative relationship), and between the condition factor and the bottom temperature (positive relationship) (Table 3). However, the condition factor was not correlated with the other indicators (Table 3).

\section{Spatial variations of growth indicators}

\author{
Recent growth index $(R G)$
}

Values of the recent growth indicator varied significantly with regard to nursery areas (Table 2, Fig. $3 c)$. Mean increment widths of juveniles from the Bay of Vilaine (1), the Loire estuary (2) and the Bay of Bourgneuf (3) were comparable but significantly greater than those from the Pertuis Breton (4), the Pertuis Antioche (5) and the Gironde estuary sites, which were not significantly different. Mean increment widths were inversely correlated with the bottom temperature (Table 3).

\section{O-group juvenile sole mean total length}

Mean total lengths displayed significant differences between sites (Table 3). Juveniles from the Bay of Vilaine (1) had significantly higher sizes values than those from the Loire estuary (2) and the Pertuis Breton (4), which in turn showed a greater size than those from the Bay of Bourgneuf (3), the Pertuis Antioche (5) and the Gironde estuary (6) (Table 2, Fig. 3d). A significant positive linear relationship was found between increment widths and 0group mean total length (Table 3 ).

\section{DISCUSSION}

\section{Use of condition indices}

\section{Biochemical indicator}

Nucleic acids have provided useful tools for assessing the instantaneous growth rate and condition of both larval and juvenile fish (Fukuda et al., 2001; Kuropat at al., 2002). Several authors have suggested that the RNA/DNA ratio is more related to the nutritional condition than to the growth (Miglavs and Jobling, 1989; Bergeron, 1997). In the present study, this index was not correlated with the recent growth index or with 0-group mean length. The estimations of the RNA/DNA ratio showed that juvenile soles from the Bay of Vilaine and the Pertuis Antioche displayed lower values for this index than those from the other nursery areas. Nevertheless, the important result was that for each site, the mean RNA/DNA ratio was greater than 2, which is supposed to be a critical threshold of food 
TABLE 3. - Correlation coefficients between RNA/DNA ratios, R condition factor (mg), RG recent growth index (mean width of the last 10day increments $(\mu \mathrm{m})$ ), $\mathrm{L}$ total length $(\mathrm{cm})$ and $\mathrm{D}$ density $\left(\mathrm{ind} / 10000 \mathrm{~m}^{2}\right.$ ) of total 0-group juvenile sole catches computed from the survey, $\mathrm{T}$ bottom temperature $\left({ }^{\circ} \mathrm{C}\right)$ and latitude.

\begin{tabular}{|c|c|c|c|c|c|c|c|}
\hline RNA/DNA & RNA/DNA & $\begin{array}{l}\mathrm{R} \\
-\end{array}$ & $\begin{array}{r}\mathrm{RG} \\
-\end{array}$ & $\begin{array}{l}\mathrm{L} \\
-\end{array}$ & $\begin{array}{c}\mathrm{D} \\
-\end{array}$ & $\begin{array}{l}\mathrm{T} \\
-\end{array}$ & latitude \\
\hline $\mathrm{R}$ & & - & - & - & $0.033 *$ & $0.032 *$ & - \\
\hline RG & & & - & $0.175^{* *}$ & - & $0.177 * *$ & $0.283 * * *$ \\
\hline $\mathrm{L}$ & & & & - & - & $0.210 * * *$ & $0.627 * * *$ \\
\hline D & & & & & - & 0.378 *** & $0.131 * * *$ \\
\hline $\mathrm{T}$ & & & & & & - & $0.667 * * *$ \\
\hline
\end{tabular}

$* \mathrm{p}<0.05, * * \mathrm{p}<0.01, * * * \mathrm{p}<0.001$

deprivation for juvenile sole (Richard et al., 1991). This suggested that juvenile soles find favourable feeding conditions in each nursery ground in autumn, at least in the short term. Comparable results were obtained in the southern Bight of the North Sea by Gilliers et al. (2004) using the same indicator. Studies on juvenile soles generally conclude that growth rates of the 0-group in nurseries are generally maximal and that food is present in excess and therefore never growth-limiting (Rogers, 1994; Amara et al., 2001). The same was concluded for the growth of 0-group plaice in different nursery grounds (e.g. Pihl et al., 2000; Amara and Paul, 2003). Nevertheless, the RNA/DNA ratio is a short-term indicator because its value can vary from 30 to $40 \mathrm{~h}$ after feeding (J.P. Bergeron, pers. comm.). High frequency assessments of the RNA/DNA ratio would be required to provide a reliable estimation of the juvenile nutritional status over a study lasting several months. In this type of study, it may be more appropriate to use storage indices such as the triacylglycerol/ sterol ratio (Fraser, 1989; Suthers et al., 1992; Lloret et al., 2003), which may be more integrative of the past feeding history.

\section{Condition factor $(R)$}

The study of condition is a common practice in fisheries ecology and is usually based on lengthweight data. Morphometric parameters provide simple condition indices which are still widely used (Suthers, 1998). The key assumption is that for a given length, a heavier fish is in better condition. We used the residuals derived from juveniles' logged length-weight relationship as a condition factor. Regardless of fish size, it should be a reliable index (Suthers, 1998). The condition of juveniles varied between the 6 nursery areas but did not show a consistent pattern. Juveniles from the Pertuis Antioche displayed the lowest values for this index.
Though the highest densities of 0-group juvenile soles were found in the nursery area located in the Pertuis Breton, there is only a low correlation between these two parameters. Our results did not provide evidence for density-dependent effects on juvenile sole condition.

\section{Use of growth indicators}

Daily patterns recorded in otolith microstructure are useful for measuring growth rates of fish (Campana and Neilson, 1985). Several studies have demonstrated that it is possible to estimate the growth rate by measuring increment widths (Hovenkamp and Witte, 1991; Stunz et al., 2002). Key assumptions for these uses are that the distance between increments is proportional to the somatic growth rate and that increments occur daily (Campana and Neilson, 1985), which were verified for this study. Spatial comparisons of the recent growth index measured on juvenile soles in the Bay of Biscay revealed consistent variations in growth between nurseries. Individuals from the two southernmost nurseries areas, the Pertuis Antioche and the Gironde estuary, showed narrower increment widths and are therefore likely to have slower growth rates than individuals from northern areas. 0group mean length appeared to confirm this result as individuals from these two sites are smaller. However, it was impossible to get the absolute age of juveniles from otolith microstructure analysis because of its shape. Differences in common sole spawning periods in the Bay of Biscay have been reported by Arbault et al. (1986). However, the spatial and temporal distributions of sole eggs did not appear to display a latitudinal pattern. Hence, the gradient of growth may not be age-dependent. Both genetic and environmental factors are known to affect the rate of somatic growth in fish. Previous studies (Autem and Kotulas, 1987; Exadactylos et al., 2001) showed that the juvenile soles caught in 
different nurseries in the Bay of Biscay were genetically homogeneous, which suggests that 0-group juvenile growth differences between nurseries may be due neither to genetic heterogeneities nor to differences of temperatures between sites (Le Pape et al., 2003). Hence, this geographical gradient in biological performance is not explained by known natural factors, and the influence of other factors related to human activities must be considered. Concerning the influence of temperature, as in most fish species in temperate regions, the growth rate of young soles (Solea solea) is related to the water temperature (Fonds, 1975). Higher temperatures are more favourable for juvenile sole that inhabit warm shallow waters. Therefore, our results showed that the recent growth and the length of the juvenile were, surprisingly, inversely related to the water temperature.

To conclude, given our results and the fact that temperature and food are the two most important factors governing fish growth (Fonds, 1975), it seems unlikely that the low growth indicators found for juvenile sole collected in the nursery areas of the Pertuis Antioche and the Gironde estuary resulted from differences in water temperature, food availability, genetic differences or age differences. Hence, the low growth performances of juvenile sole in the southernmost nurseries is not explained by known natural factors, and the influence of other factors such as those related to human activities must be considered. In a another study Gilliers et al. (in press) examine these growth indicators in relation to the contamination of the coastal water with chemical contaminants, notably heavy metals such as cadmium, which has been shown to be highly discharged in the Gironde estuary and the Pertuis Antioche.

These initial results do not yet enable us to determine all the factors responsible for the variations in the growth and condition of the juvenile soles in the Bay of Biscay, or to conclude that the juvenile soles find habitats of better quality in the northern nursery areas.

\section{What is a good indicator of anthropogenic impacts?}

As observed in this study, several authors have found a poor correlation between separate indices, and subsequently advised the simultaneous use of various indicators to provide reliable estimations
(McCormick and Molony, 1993; Suthers et al., 1992; Suthers 1998). Therefore, the choice of the indicators needs to be discussed and depends on the type of study. For example, in the present study, short-term and fluctuating biochemical indices such as the RNA/DNA ratio do not appear to be useful. On the other hand, morphometric indices based on length-weight data seem to be more relevant indicators of fish condition and habitat quality, as they integrate the whole juvenile life-history in the nursery ground. The results obtained from growth indicators at the scale of the year 2000 need to be confirmed by year-to year comparisons and environmental data related to anthropogenic factors.

\section{Consequences of the Erika oil spill}

The oil spill of the Erika occurred in December 1999 and involved the spread of 20,000 tonnes of fuel over more than $400 \mathrm{~km}$ of coast in the French part of the Bay of Biscay, in particular the 3 northern nursery areas investigated 9 months later in this study. The fuel arrivals took different shapes (balls, patties, layers, etc.) and touched all the environments. Data on shellfish collected near the Loire estuary area by the Réseau National d'Observation de la Qualité du Milieu Marin (RNO), IFREMER and the French Ministry for Ecology and Sustainable Development showed that very high values of PAH (3 to $5000 \mu \mathrm{g} \cdot \mathrm{kg}^{-1}$ dry weight of shellfish) were reached for several months after the oil spill in coastal shellfish-farming areas (the chronic contamination level of this part of the coast was situated at around $150 \mu \mathrm{g} \cdot \mathrm{kg}^{-1}$ dry weight for $\mathrm{PAH})$. Coastal shellfish farming underwent a long period of closure. Moreover, further studies on contaminations levels demonstrated that the contamination profiles analysed 2 years after the Erika oil spill were still different from the initial state (Jeanneret et al., 2002).

According to these results on contamination levels, we hypothesised that 0 -group juveniles might have found damaged habitats when they settled a few months after the oil spill on exposed nursery grounds. Subsequently, they might have lower growth and condition when sampled a few months later at the end of their first growing season. The different growth and condition indices used here are affected by a number of divergent sources of variability, and it is very difficult to draw a quantitative conclusion from this approach. Nevertheless, the 
values of growth and condition indicators measured on juvenile soles sampled in September 2000 from nursery grounds exposed to the Erika oil spill in December 1999 were relatively high. The estimated densities support these estimations. These results lead us to suggest that there was no obvious impact of this event on the quality of the habitats of young soles. However, they should also be confirmed by year-to year comparisons.

\section{ACKNOWLEDGEMENTS}

This study was supported by the French Ministry for Ecology and Sustainable Development (Ministère de l'Aménagement du Territoire et de l'Environnement MATE) as part of the ECTOPHY national programme. The authors are grateful to their colleagues and the crew of the R.V. Gwen Drez who participated in the NURSE 2000 cruise. They also wish to thank the anonymous reviewers for their fruitful comments.

\section{REFERENCES}

Able, K.W. - 1999. Measures of Fish Habitat Quality : Examples from a National Estuarine Research Reserve. In: L.R. Benaka (eds.), Fish habitat: essential fish habitat and rehabilitation, Am. Fish. Soc. Bethesda, Symposium 22, pp. 134-147. Bethesda, Maryland.

Able, K.W., J.P. Manderson and A.L. Studholme. - 1999. Habitat quality for shallow water fishes in urban estuary: the effect of man-made structures on growth. Mar. Ecol. Prog. Ser., 187: 227-235

Amara, R., P. Laffargue, J.M. Dewarumez and C. Maryniak. 2001. Feeding ecology and growth of 0-group flatfishes (sole, dab and plaice) on a nursery ground (Southern Bight of North Sea). J. Fish Biol., 58: 788-803.

Amara, R. and C. Paul. - 2003. Seasonal patterns in the fish and epibenthic crustaceans community of an intertidal zone with particular reference to the population dynamics of plaice and brown shrimp. Estuar. Coast. Shelf Sci., 56: 1-13.

Arbault, S., P. Camus and C. Le Bec. - 1986. Estimation du stock de sole (Solea vulgaris, Quensel 1806) dans le Golfe de Gascogne à partir de la production d'œufs. J. Appl. Ichtyol., 4: 145-146.

Autem, M. and G. Kotulas. - 1987. Hétérogénéité et évolution estivales des pools génétiques de Solea vulgaris en baie de Vilaine et dans les Pertuis Charentais. Rapp. Ifremer, 41 pp., Univ. Montpellier.

Bergeron, J.P. - 1997. Nucleic acids in ichthyoplancton ecology: a review, with emphasis on recent advances for new perspectives. J. Fish Biol., 51: 284-302.

Blackwell, B.G., M.L. Brown and D.W. Willis. - 2000. Relative Weight (Wr) Status and Current Use in Fisheries Assessment and Management. Rev. Fish. Sci., 8(1): 1-44.

Burke, J.S., D.S. Peters and P.J. Hanson. - 1993. Morphological indices and otolith microstructure of Atlanltic croaker, Micropogonias undulatus, as indicators of habitat quality along an estuarine pollution gradient. Envir. Biol. Fishes, 36: 25-33.

Campana, S.E. and J.D. Neilson. D.S. - 1985. Microstructure of fish otolith. Can. J. Fish. Aquat. Sci., 42: 1014-1032.

Campana, S.E., J.A. Gagné and J. Munro. - 1987. Otolith microstructure of larval herring (Clupea harengus): image or reality? Can. J. Fish. Aquat. Sci., 44: 1922-1929.

Costanza, R., R . Darge, R. Degroot, S. Farber, M. Grasso, B. Hannon, K. Limburg, S. Naeem, R.V. O’Neill, J. Paruelo, R.G. Raskin, P. Sutton and M. Vandenbelt. - 1997. The value of the world's ecosystem services and natural capital. Nature, 387: 253-260.

Désaunay, Y., D. Guérault, J. Martin, O. Le Pape, P. Grellier, G. Bocquené, T. Burgeot, D. Ménard, J. Le Merrer, O. Mazéas and A. Togola. - 2003. Suivi des peuplements (ichtyofaune et invertébrés) des sites côtiers du nord du golfe de Gascogne. Conséquences écologiques et écotoxicologique de la marée noire " Erika », pp. 8-24. Projet n ${ }^{\circ}$ ECTOPHY-nourriceries, Contrat MATE-INERIS, Rapp. Ifremer, Nantes.

Dorel, D., C. Koutsikopoulos, Y. Désaunay and J. Marchand. 1991, Seasonal distribution of young sole (Solea solea (L.)) in the nursery ground of the Bay of Vilaine (northern Bay of Biscay). Neth. J. Sea Res., 27: 1-23.

Engel, D.W., G. Thayer and D.W. Evans. - 1999. Linkages between fishery habitat quality, stressors, and fishery populations. Envir. Sci. Pol., 2: 465-475.

Exadactylos, A., A.Y. Troumbis, A.J. Geffen and J.P. Thorpe. 2001. Population structure of the Dover sole, Solea solea L., in the Atlantic using randomly amplified polymorphic DNA (PCR-RADP) marking. The life history, Dynamics and exploitation of living marine resources: Advances in knowledge and methodology.

Fonds, M. - 1975. The influence of temperature and salinity on growth of young sole, Solea solea L. 10 ${ }^{\text {th }}$ Eur. Symp. Mar. Biol., 109-125. Ostende, Belgium.

Fraser, A.J. - 1989. Triacylglycerol content as a condition index for fish, bivalve and crustacean larvae. Can. J. Fish. Aquat. Sci., 46: $1868-1873$.

Fukuda, M., H. Sako, T. Shigeta and R. Shibata. - 2001. Relationship between growth and biochemical indices in laboratory-reared juveniles Japanese flounder (Paralichtys olivaceus) and its application to wild fish. Mar. Biol., 138: 47-55.

Gibson, R.N. - 1994. Impact of habitat quality and quantity on the recruitment of juvenile flatfishes. Neth. J. Sea Res. 32: 191-206.

Gilliers, C., R. Amara, J.P. Bergeron and O. Le Pape. - 2004. Comparison of growth and condition indices of flatfish juvenile (sole, dab and plaice) in different coastal nursery grounds. Envir. Biol. Fishes, 71(2): 189-198.

Gilliers, C., O. Le Pape, J. Morin, Y. Desaunay and R. Amara. - (in press). Estimation of essential fish habitat quality with indicators of fishdensity and growth. A study of the common sole (Solea solea, L.) onnursery grounds. Estuar. Coast. Shelf Sci.

Hovenkamp, F. and J.I.J. Witte. - 1991. Growth, otolith growth and RNA/DNA ratios of larval plaice Pleuronectes platessa in the North Sea 1987 to 1989. Mar. Ecol. Prog. Ser. 70: 105-116.

Jeanneret, H., S. Chantereau and G. Ratiskol. - 2002. The limitation of the consequences on exploited natural resources : management of shellfish farming areas in the Erika's pollution. Environmental impact of an accidental water pollution. Les Journées du Cedre, Paris.

Karsten, U. and A. Wollenberger. - 1977. Improvement of the ethidium bromide method for direct estimation of DNA and RNA in cell and tissue homogenates. Analyt. Biochem., 77: 464-470.

Koutsikopoulos, C., Y. Désaunay, D. Dorel and J. Marchand. 1989. Role of coastal areas in the life history of sole (Solea solea (L.)) in the Bay of Biscay. Topics Mar. Biol. Sci. Mar., 53(2-3): 567-575.

Koutsikopoulos, C., L. Fortier and J.A. Gagné. - 1991. Cross-shelf dispersion of Dover sole eggs and larvae (Solea solea) in Biscay Bay and recruitment to inshore nurseries. J. Plankton Res., 13: 923-945.

Koutsikopoulos, C. and N. Lacroix. - 1992. Distribution and abundance of sole (Solea solea (L.)) eggs and larvae in the Bay of Biscay between 1986 and 1999. Neth. J. Sea Res., 29: 81-91.

Koutsikopoulos, C., D. Dorel and Y. Désaunay. - 1995. Movement of sole (Solea solea) in the Bay of Biscay: coastal environment and spawning migration. J. Mar. Biol. Ass. U. K., 75: 109-126.

Kuropat, C., R. Mercaldo-Allen, E. Caldarone, R. Goldberg, B. Phelan and F. Thurberg. - 2002. Evaluation of RNA concentration as an indicator of growth in the young-of-the-year winter flounder Pseudopleuronectes americanus and tautog Tautoga 
onitis. Mar. Ecol. Prog. Ser., 230: 265-274.

Lagardère, F. - 1989. Influence of feeding conditions and temperature on the growth rate and otolith increment deposition of larval Dover sole (Solea solea (L.)). Rapp. P.-v. Réun. Cons. Perm. Int. Explor. Mer., 191: 390-399.

Le Cann, B. - 1990. Barotropic tidal dynamics of the Bay of Biscay shelf: observations, numerical modelling and physical interpretation. Cont. Shelf Res., 10: 723-758.

Le Pape, O., F. Chauvet, S. Mahévas, P. Lazure, D. Guérault and Y. Désaunay. - 2003. Quantitative description of habitat suitability for the juvenile common sole (Solea solea L.) in the Bay of Biscay (France) and the contribution of different habitats to the adult population. J. Sea Res., 50: 139-149.

Le Pecq, J.B. and C. Paoletti. - 1966. A new fluorimetric method for RNA and DNA determination. Analyt. Biochem., 17: 100-107.

Lloret, J. and S. Planes. - 2003. Condition, feeding and reproductive potential of white seabream (Diplodus sargus) as indicators of habitat quality and the effect of reserve protection in the northwestern Mediterranean. Mar. Ecol. Prog. Ser., 248: 197-208.

Mc Cormick, M.I., and B.W. Molony. - 1993. Quality of the reef fish Upeneus tragula (Mullidae) at settlement: is size a good indicator of condition? Mar. Ecol. Prog. Ser., 98: 45-54.

Marchand, J. and G. Masson. - 1989. Process of estuarine colonization by 0 -group sole (Solea solea) in the Vilaine estuary (1986-1989): hydrological conditions, behaviour and feeding activity in the Vilaine estuary. Rapp. P.-v. Réun. Cons. Perm. Int. Explor. Mer., 191: 287-295.

Miglavs, I. And M. Jobling. - 1989. Effect of feeding regime on food consumption, growth rates and tissue nucleic acids in juvenile Arctic charr, Salvelinus alpinus, with particular respect to compensatory growth. J. Fish Biol., 34: 947-957.

Minello, T.J. - 1999. Nekton densities in shallow estuarine habitats of Texas and Louisiana and the identification of essential fish habitat. In: L.R. Benaka (ed.), Fish habitat: essential fish habitat and rehabilitation, Am. Fish. Soc. Bethesda, Symposium 22, pp 43-75. Bethesda, Maryland.

Phelan, B.A., R. Goldberg, A.J. Bejda, J. Pereira, S. Hagan, P.
Clark, A.L. Studholme, A. Calabrese and K.W. Able - 2000. Estuarine and habitat-related differences in growth rates of young of the year winter flounder (Pseudopleuronectes americanus) and tautog (Tautoga onitis) in three north-eastern US estuaries. J. Exp. Mar. Biol. Ecol., 247: 1-28.

Pihl, L., J. Modin and H. Wennhage. - 2000. Spatial distribution patterns of newly settled plaice (Pleuronectes platessa L.) along the Swedish Skagerrak archipelago. J. Sea. Res., 44: 65-80.

Richard, P., J.P. Bergeron, M. Boulhic, R. Galois and J. Person-Le Ruyet. - 1991. Effect of starvation on RNA, DNA and protein content of laboratory-reared larvae and juveniles of Solea solea. Mar. Ecol. Prog. Ser., 72: 69-77.

Riou, P., O. Le Pape and S.I. Rogers. - 2001. Relative contributions of different sole and plaice nurseries to the adult population in the eastern Channel: application of a combined method using generalized linear models and a geographic information system. Aquat. Living Resour., 14: 125-135.

Rogers, S.I. - 1994. Species composition and production of sole, Solea solea L., in a flatfish nursery ground on the North Wales coast. UK Aqu. Fish. Man., 25: 161-177.

Sogard, S. and K.W. Able. - 1992. Growth variation of newly settled winter flounder (Pseudopleurectes americanus) in New Jersey estuaries as determined by otolith microstructure. Neth J. Sea Res., 29: 163-172.

Stunz, G.W., T.J. Minello and P.S. Levin. - 2002, Growth of newly settled red drum Sciaenops ocellatus in different estuarine habitat types. Mar. Ecol. Prog. Ser., 238: 227-236.

Suthers, I.M., A. Fraser and K.T. Frank. - 1992. Comparison of lipid, otolith and morphometric condition indices of pelagic juvenile cod (Gadus morhua) from the Canadian Atlantic. Mar. Ecol. Prog. Ser., 84: 31-40.

Suthers, I.M. - 1998. Bigger? Fatter? Or is faster growth better? Considerations on condition in larval and juvenile coral-reef fish. Aust. J. Ecol., 23: 265-273.

Received June 28, 2002. Accepted November 24, 2004. 